\title{
MEASUREMENTS OF ESCAPING ALPHAS IN THE TFTR DT EXPERIMENTS
}

by

\author{
S.J. ZWEBEN, D.S. DARROW, H.W. HERRMANN, ET AL.
}

Published in the Proceedings of the 21st European Physical Society's Division of Plasma Physics Meeting (June 27-July 1, 1994, Montpellier, France), published by EPS 1994.

\section{Work supported by U.S. Department of Energy Contract DE- AC02-76-CHO-3073.}

\section{DISCLAIMER}

This report was prepared as an account of work sponsored by an agency of the United States Government. Neither the United States Government nor any agency thereof, nor any of their employees, makes any warranty, express or implied, or assumes any legal liability or responsibility for the accuracy, completeness, or usefulness of any information, apparatus, product, or process disclosed, or represents that its use would not infringe privately owned rights. Reference herein to any specific commercial product, process, or service by trade name, trademark, manufacturer, or otherwise does not necessarily constitute or imply its endorsement, recommendation, or favoring by the United States Government or any agency thereof. The views and opinions of authors expressed herein do not necessarily state or reflect those of the United States Government or any agency thereof.

\section{Princeton University Plasma Physics Laboratory}




\section{DISCLAIMER}

Portions of this document may be illegible in electronic image products. Images are produced from the best available original document. 


\section{Alpha Loss in the $45^{\circ}$ Detector}

The DT alpha loss to the detector $45^{\circ}$ below the outboard midplane is shown vs. plasma current in Fig. 3 for the same plasmas of Fig. 1. In contrast to the results at $90^{\circ}$, the neutron-normalized alpha loss at this location does not follow the predicted first-orbit alpha loss vs. plasma current. This behavior is not due to any "collective" alpha effect, since the alpha loss at $45^{\circ}$ is independent on the DT neutron rate at a fixed current, and since a similar current dependence is obtained for DD fusion products. Therefore this behavior is a "single particle" effect, possibly due to stochastic toroidal field (TF) ripple diffusion, such as analyzed previously for the midplane $\left(20^{\circ}\right)$ detector in $\mathrm{DD}[5]$.

However, calculations of stochastic TF ripple diffusion in TFTR done using the collisionless bounce-averaged MAPLOS code[5] predict that the collisionless TF ripple loss should occur at poloidal angles $\leq 30^{\circ}$ below the outboard midplane, so can not explain the non-first-orbit loss component at $45^{\circ}$ in Fig. 3. The collisional guiding center code ORBIT predicts higher TF ripple loss than MAPLOS, with a global alpha loss at $\mathrm{Ip}=1.8 \mathrm{MA}$ about a factor of 3 above the first-orbit loss, but also predicts that this TF-rippleinduced loss should be $\leq 30^{\circ}$ below the outboard midplane[6]. Thus neither code is presently able to explain the trend shown in Fig. 3.

\section{Time Dependence of Alpha Loss}

The time dependence of the alpha loss in the $90^{\circ}$ detector follows closely the time dependence of the DT neutron rate during and after NBI, as expected from first-orbit loss. For the $45^{\circ}$ detector there is a gradual $\approx 50 \%$ increase in the alpha loss rate per neutron over $\approx 1$ sec during NBI, but no large increase after NBI. This may be consistent with the relatively rapid process of stochastic $\mathrm{TF}$ ripple diffusion ( $\leq 10 \mathrm{msec}$ ), but not with a significant collisional loss over the timescale of alpha thermalization $\quad \approx 0.6$ sec). There was also no significant change in the gyroradius distribution after NBI in either detector, such as might be calculated from a delayed loss process.

The alpha loss in the DT discharges described above was not visibly affected by coherent MHD activity. The clearest examples of MHD-induced alpha loss have occurred during major and minor disruptions, as seen previously for DD fusion products[1]. Fig. 4 shows the alpha loss in the $90^{\circ}$ detector increasing by a factor of $\approx 100$ above the first-orbit loss level just before a major disruption. This pre-disruptive alpha loss could be a problem for ITER, since the alphas may be lost at different places than the thermal plasma. No D'T alpha particle loss associated with Alfven waves, such as the TAE mode, has yet been seen[7]. 


\section{Measurements of Escaping Alphas in the TFTR DT Experiments}

S.J. Zweben, D. S. Darrow, H. W. Herrmann, R.V. Budny, C.S. Chang ${ }^{\dagger}$, C.Z. Cheng, G. Y. Fu, D. L. Jassby, M. H. Redi, J. Schivell, S. Scott, D.A. Spong ${ }^{\ddagger}$, J. D. Strachan, K. Tobita ${ }^{*}$, K. M. Young, V. Zaveriaev ${ }^{+}$, and the TFTR Group

Princeton Plasma Physics Laboratory, Princeton, New Jersey, USA

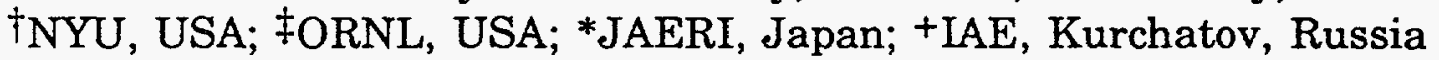

Alpha particle loss to the wall of TFTR has been measured during the initial TFTR DT run period. These measurements were made with the same lost alpha scintillator detector system used previously for DD fusion products[1], except for a switch of the scintillator material from zinc sulfide (P31) to yttrium aluminate (P46) to insure a linear response up to the maximum alpha flux expected in DT[2]. The alpha loss signals in DT are $\approx 100$ times larger than the DD fusion product loss signals, as expected from the neutron rates and the relative sensitivity to DT vs. DD fusion products.

\section{Alpha Loss in the $90^{\circ}$ Detector}

The DT alpha loss at the vessel bottom $90^{\circ}$ below the outboard midplane is generally consistent with the calculated first-orbit loss of 3.5 $\mathrm{MeV}$ alphas. This is illustrated in Fig. 1, which shows the total alpha loss rate to the $90^{\circ}$ detector normalized to the DT neutron rate as a function of plasma current $(R=2.52 \mathrm{~m})$. When the data at $\mathrm{I}=0.6 \mathrm{MA}$ are normalized to the calculated first-orbit loss to this detector, the data at Ip=1.0-2.5 MA fit the calculated first-orbit loss to within the joint uncertainties in measurement and modeling $(\approx 30-40 \%)$. The absolute value of the alpha loss at $90^{\circ}$ in $\mathrm{DT}$ is also consistent with this model, at least to within the factorof-two uncertainty of an absolute detector calibration. The alpha loss per neutron at $\mathrm{Ip}=2.0 \mathrm{MA}$ does not change more than $\approx 20 \%$ over the entire range of DT neutron rates from $2 \%$ tritium to $50 / 50 \mathrm{DT}$, i.e. over $=0.05$ $2.2 \times 10^{18}$ neutrons/sec, indicating the absence of any collective alpha loss mechanism in these plasmas with $\beta_{\alpha}(0) \leq 0.25 \%$.

The measured pitch angle and gyroradius distributions for DT alpha loss in the $90^{\circ}$ detector are shown in Fig. 2 for a discharge at Ip=2.5 MA with 7.4 MW of fusion power. The distributions in DT are consistent with the expected alpha particle first-orbit loss, the peak of which is calculated to be at the " $\mathrm{x}$ " in the figure. Also shown in Fig. 2 is a DD discharge with the same plasma parameters and a fairly similar loss pattern, as expected for DD fusion products, but with a small "delayed loss" feature similar to that previously observed in DD[3]. The apparent absence of this delayed loss in the $90^{\circ}$ detector in DT is at least qualitatively consistent with the hypothesis that in DD it was due to classical collisional pitch angle scattering of the 1 $\mathrm{MeV}$ tritons, which is much reduced for $3.5 \mathrm{MeV}$ alphas[1,4]. 


\section{Discussion}

The DT alpha loss detected $90^{\circ}$ below the outboard midplane is consistent with the expected first-orbit loss, while the alpha loss detected $45^{\circ}$ below the outboard midplane is significantly higher than the expected firstorbit loss. In all cases the relative alpha loss per neutron does not vary significantly with the DT neutron rate, so the non-first orbit losses at $45^{\circ}$ are not due to any collective alpha particle effect.

Somewhat similar non-first orbit loss was previously described for DD fusion products in the $20^{\circ}$ detector, and was explained in terms of collisionless stochastic TF ripple diffusion[5]. The recent guiding center code calculations of collisional TF ripple-induced alpha loss have shown a significant collisional alpha loss effect[6], but have not yet explained the increased alpha loss seen at $45^{\circ}$. Such calculations have predicted the loss of neutral beam ion loss in JT-60U[8], and will be continued with improved modeling of the TFTR magnetic fields and better statistics. Fokker-Planck calculations are also in progress to model the collisional loss into these detectors[9].

So far there have been no signs of any alpha particle loss associated specifically with full DT operation, such as might have been expected from collective alpha particle instabilities. Experiments designed to stimulate such instabilities are reported elsewhere[10].

References:

1. S. J. Zweben, R. Boivin, D.S. Darrow, et al, Proc. 14th IAEA Conference on Plasma Physics and Controlled Fusion, Wurzburg (IAEA, 1993).

2. D.S. Darrow, et al, to be published in Rev. Sci. Inst. (1994).

3. S.J. Zweben, D.S. Darrow, et al, Nucl. Fus. 33, 705 (1993).

4. C.S. Chang, S.J. Zweben, et al, to be published in Plasma Physics (1994).

5. R.L. Boivin, S.J. Zweben, and R.B. White, Nucl. Fusion 33, 449 (1993).

6. M. H. Redi, et al, "Collisional Stochastic Ripple Diffusion of Alpha Particles and Beam Ions in TFTR", in preparation (1994)

7. J.D. Strachan, et al, Phys. Rev. Lett. 72, 3530 (1994).

8. K. Tobita, Phys. Rev. Lett. 69, 3060 (1992)

9. V. Yavorski, private communication

10. E. D. Fredrickson, this conference

Acknowledgment:

This work was performed under contract DE-AC02-76CH0-3073. 




Fig. 1: The total alpha particle loss $90^{\circ}$ below the midplane vs. $I_{p}$. The vertical axis is the calculated alpha loss fraction into this detector, e.g. $\approx 10^{10}$ alphas $/ \mathrm{sec}$ for an $I_{p}=2.0 \mathrm{MA}$ discharge with $2 \times 10^{18}$ neutrons/sec.

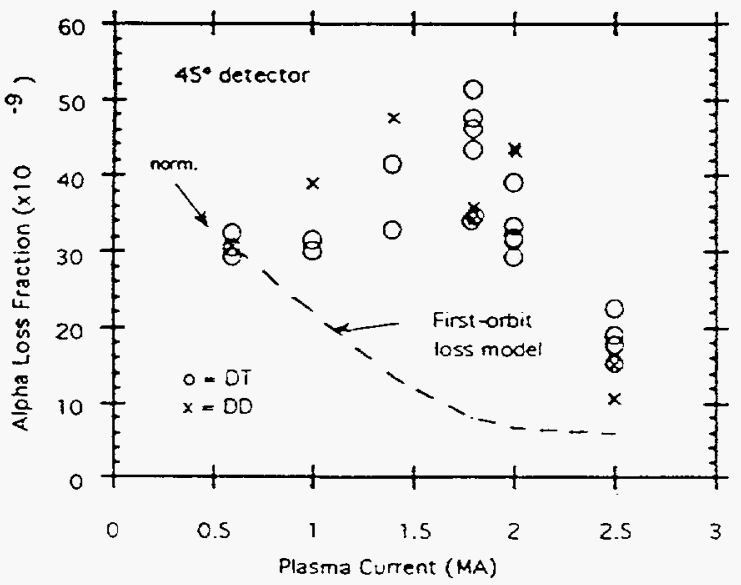

Fig. 3: The total alpha particle loss $45^{\circ}$ below the midplane vs. $l_{p}$. Since a similar non-first orbin loss vs. current is seen in DD, this is a "single particle" and not a "collective" alpha effect.
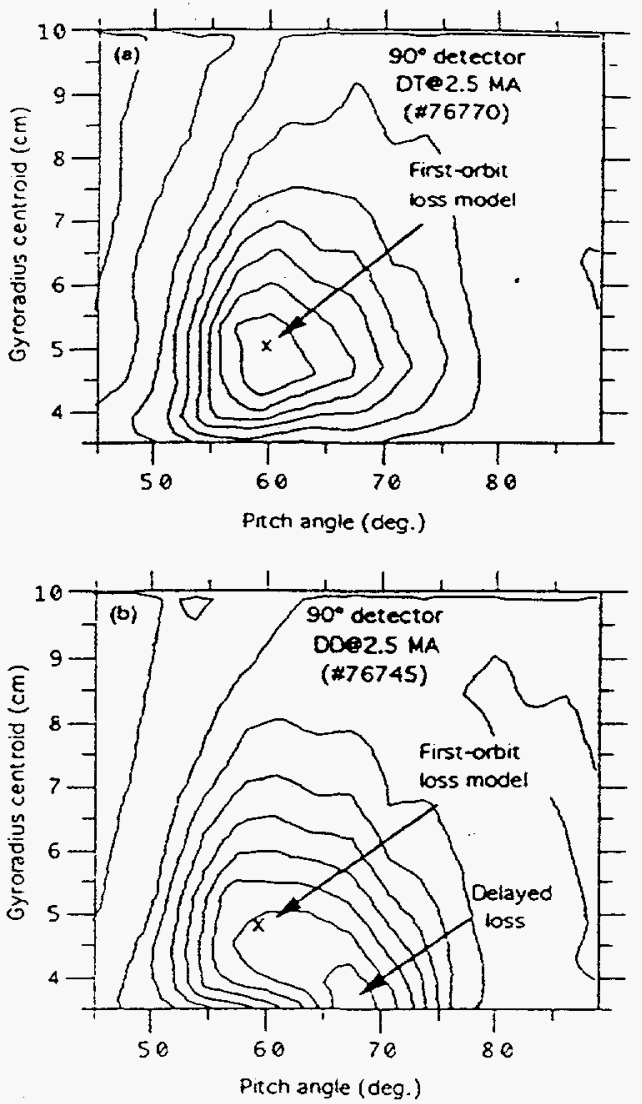

Fig. 2: Pitch angle vs. gyroradius distributions of alpha loss at $l_{p}=2.5$ MA for similar DT and DD discharges at $R=2.52 \mathrm{~m}$. In DT the pattern is consistent with first-orbit loss when the instrumental broadening effects are included. The delayed loss in DD which is not seen in DT is most likely due to collisional losses of $1 \mathrm{MeV}$ tritons in DD.
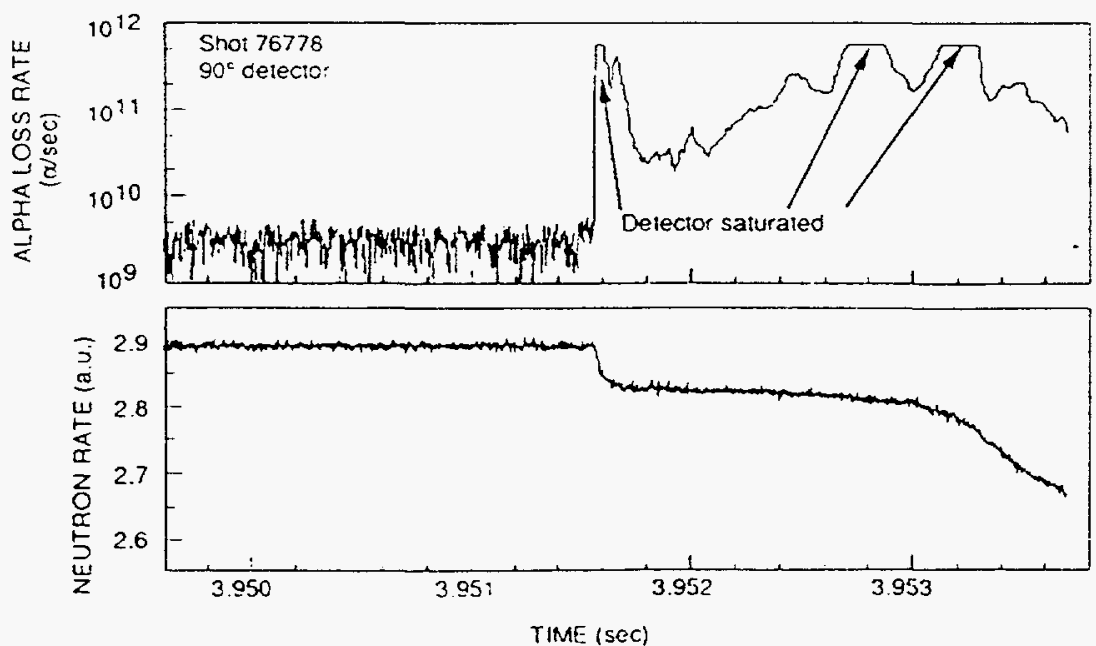

Fig. 4: Time dependence of the OT alpha loss at $90^{\circ}$ during a high power disruption at $\mathrm{I}_{\mathrm{p}}=2.5 \mathrm{MA}$. There is a factor of $=100$ increase in the alpha loss a few msec before the stant of the plasma current decay. The alpha loss at $90^{\circ}$ was larger than the loss in the other detectors. 
Dr. F. Paoloni, Univ. of Wollongong, AUSTRALIA

Prof. R.C. Cross, Univ. of Sydney, AUSTRALIA

Plasma Research Lab., Australian Nat. Univ., AUSTRALIA

Prof. I.A. Jones, Flinders Univ, AUSTRALIA

Prof. F. Cap, Inst. for Theoretical Physics, AUSTRIA

Prof. M. Heindler, Institut für Theoretische Physik, AUSTRIA

Prof. M. Goossens, Astronomisch Instituut, BELGIUM

Ecole Royale Militaire, Lab. de Phy. Plasmas, BELGIUM

Commission-European, DG. XII-Fusion Prog., BELGIUM

Prof. R. Bouciqué, Rijksuniversiteit Gent, BELGIUM

Dr. P.H. Sakanaka, Instituto Fisica, BRAZIL

Prof. Dr. I.C. Nascimento, Instituto Fisica, Sao Paulo, BRAZIL Instituto Nacional De Pesquisas Espaciais-INPE, BRAZIL

Documents Office, Atomic Energy of Canada Lid., CANADA

Ms. M. Morin, CCFMTokamak de Varennes, CANADA

Dr. M.P. Bachynski, MPB Technologies, Inc., CANADA

Dr. H.M. Skarsgard, Univ. of Saskatchewan, CANADA

Prof. J. Teichmann, Univ. of Montreal, CANADA

Prof. S.R. Sreenivasan, Univ. of Calgary, CANADA

Prot. T.W. Johnston, INRS-Energie, CANADA

Dr. R. Bolton, Centre canadien de fusion magnétique, CANADA

Dr. C.R. James, Univ. of Alberta, CANADA

Dr. P. Lukác, Komenského Universzita, CZECHO-SLOVAKIA

The Librarian, Culham Laboratory, ENGLAND

Library, R61, Rutherford Appleton Laboratory, ENGLAND

Mrs. S.A. Hutchinson, JET Library, ENGLAND

Dr. S.C. Sharma, Univ. of South Pacific, FIJI ISLANDS

P. Mähönen, Univ. of Helsinki, FINLAND

Prof. M.N. Bussac, Ecole Polytechnique, FRANCE

C. Mouttet, Lab. de Physique des Milieux lonisés, FRANCE

J. Radet, CEN/CADARACHE - Bat 506, FRANCE

Prof. E. Economou, Univ. of Crete, GREECE

Ms. C. Rinni, Univ. of loannina, GREECE

Preprint Library, Hungarian Academy of Sci., HUNGARY

Dr. B. DasGupta, Saha Inst. of Nuclear Physics, INDIA

Dr. P. Kaw, Inst. for Plasma Research, INDIA

Dr. P. Rosenau, Israel Inst. of Technology, ISRAEL

Librarian, Intemational Center for Theo Physics, ITALY

Miss C. De Palo, Associazione EURATOM-ENEA, ITALY

Dr. G. Grosso, Istituto di Fisica del Plasma, ITALY

Prof. G. Rostangni, Istituto Gas lonizzati Del Cnr, ITALY
Dr. H. Yamato, Toshiba Res \& Devel Center, JAPAN

Prof. 1. Kawakami, Hiroshima Univ., JAPAN

Prof. K. Nishikawa, Hiroshima Univ., JAPAN

Librarian, Naka Fusion Research Establishment, JAERI, JAPAN

Director, Japan Atomic Energy Research Inst., JAPAN

Prof. S. Itoh, Kyushu Univ., JAPAN

Research inio. Crr., National Instit. for Fusion Science, JAPAN

Prof. S. Tanaka, Kyoto Univ., JAPAN

Library, Kyoto Univ., JAPAN

Prof. N. Inoue, Univ. of Tokyo, JAPAN

Secretary, Plasma Section, Electrotechnical Lab., JAPAN

Dr. O. Mitarai, Kumamoto Inst. of Technology, JAPAN

Dr. G.S. Lee, Korea Basic Sci. Ctr., KOREA

J. Hyeon-Sook, Korea Atomic Energy Research Inst., KOREA

D.I. Choi, The Korea Adv. Inst. of Sci. \& Tech., KOREA

Prof. B.S. Liley, Univ. of Waikato, NEW ZEALAND

Inst of Physics, Chinese Acad Sci PEOPLE'S REP. OF CHINA Library, Inst. of Plasma Physics, PEOPLE'S REP. OF CHINA Tsinghua Univ. Library, PEOPLE'S REPUBLIC OF CHINA Z. Li, S.W. Inst Physics, PEOPLE'S REPUBLIC OF CHINA

Prof. J.A.C. Cabral, Instituto Superior Tecnico, PORTUGAL

Prof. M.A. Hellberg, Univ. of Natal, S. AFRICA

Prof. D.E. Kim, Pohang Inst. of Sci. \& Tech., SO. KOREA

Prof. C.I.E.M.A.T, Fusion Division Library, SPAIN

Dr. L. Stenflo, Univ. of UMEA, SWEDEN

Library, Royal Inst. of Technology, SWEDEN

Prof. H. Wilhelmson, Chalmers Univ. of Tech., SWEDEN

Centre Phys. Des Plasmas, Ecole Polytech, SWITZERLAND

Bibliotheek, Inst. Voor Plasma-Fysica, THE NETHERLANDS

Asst. Prof. Dr. S. Cakir, Middle East Tech. Univ., TURKEY

Dr. V.A. Glukhikh,Sci. Res. Inst. Electrophys.I Apparatus, USSR

Dr. D.D. Ryutov, Siberian Branch of Academy of Sci., USSR

Dr. G.A. Eliseev, I.V. Kurchatov Inst., USSR

Librarian, The Ukr.SSR Academy of Sciences, USSR

Dr. L.M. Kovrizhnykh, Inst. of General Physics, USSR

Kemforschungsanlage GmbH, Zentralbibliothek, W. GERMANY

Bibliothek, Inst. Für Plasmaforschung, W. GERMANY

Prof. K. Schindler, Ruhr-Universitát Bochum, W. GERMANY

Dr. F. Wagner, (ASDEX), Max-Planck-Institut, W. GERMANY

Librarian, Max-Planck-Institut, W. GERMANY 